\title{
Alles van waarde is weerloos...
}

Citation for published version (APA):

Boonen, A. E. R. C. H. (2014). Alles van waarde is weerloos... Maastricht. https://doi.org/10.26481/spe.20140214ab

Document status and date:

Published: 14/02/2014

DOI:

10.26481/spe.20140214ab

Document Version:

Publisher's PDF, also known as Version of record

\section{Please check the document version of this publication:}

- A submitted manuscript is the version of the article upon submission and before peer-review. There can be important differences between the submitted version and the official published version of record.

People interested in the research are advised to contact the author for the final version of the publication, or visit the DOI to the publisher's website.

- The final author version and the galley proof are versions of the publication after peer review.

- The final published version features the final layout of the paper including the volume, issue and page numbers.

Link to publication

\footnotetext{
General rights rights.

- You may freely distribute the URL identifying the publication in the public portal. please follow below link for the End User Agreement:

www.umlib.nl/taverne-license

Take down policy

If you believe that this document breaches copyright please contact us at:

repository@maastrichtuniversity.nl

providing details and we will investigate your claim.
}

Copyright and moral rights for the publications made accessible in the public portal are retained by the authors and/or other copyright owners and it is a condition of accessing publications that users recognise and abide by the legal requirements associated with these

- Users may download and print one copy of any publication from the public portal for the purpose of private study or research.

- You may not further distribute the material or use it for any profit-making activity or commercial gain

If the publication is distributed under the terms of Article $25 \mathrm{fa}$ of the Dutch Copyright Act, indicated by the "Taverne" license above, 
Annelies Boonen

Faculty of Health, Medicine and Life Sciences

\section{Alles van waarde is weerloos...}


Alles van waarde is weerloos...

Oratie uitgesproken bij de aanvaarding van het ambt als hoogleraar 'maatschappelijke aspecten van reumatologische aandoeningen' aan de Universiteit Maastricht

Annelies Boonen, 14 februari 2014 
er is niet meer bij weinig

noch is er minder

noch is onzeker wat er was

- wat wordt wordt willoos

- eerst als het is is het ernst

- het herinnert zich heilloos

- en blijft ijlings

alles van waarde is weerloos

wordt van aanraakbaarheid rijk

en aan alles gelijk

als het hart van de tijd

als het hart van de tijd

Uit de zeer oude zingt

Lucebert 1974

Mijnheer de rector magnificus, Zeer geachte toehoorders,

Weinigen zullen betwijfelen dat maatschappelijke aspecten van chronische ziekten, en dus reumatologische aandoeningen belangrijk zijn en aandacht verdienen.

Dat onderzoekers zich voortdurend bewust moeten zijn van het maatschappelijke belang dat hun onderzoek heeft of kan hebben, is eveneens vanzelfsprekend en toenemend een vereiste.

De vraag zou echter kunnen zijn of de arts als clinicus, de reumatoloog in de praktijk, moet rekening houden met de maatschappelijke, en in het bijzonder economische aspecten van ziekten, en welke maatschappelijk-economische aspecten het waard zijn om zijn aandacht te krijgen.

Ik wil u graag meenemen in een drieluik, waarbij elk paneel een ander maatschappelijk thema voorstelt en waarbij ik zal toelichten hoe ons onderzoek heeft bijgedragen tot het inzicht dat het waardevol kan zijn als niet alleen de arts als onderzoeker maar ook de arts in de klinische praktijk denkt en handelt vanuit een maatschappelijk perspectief. 


\section{Arts en Maatschappij}

Laten we beginnen bij het begin van het artsen beroep. De boom van Hippocrates op het eiland Kos, ruim 400 jaar voor Christus. De plek waar de vader van de geneeskunde zijn leerlingen onderwees, zijn aphorismen schreef, maar ook nadacht over de professionaliteit van de arts.

De 'arts van de eed van Hippocrates', behoorde de geneeskunde uit te oefenen vanuit een perspectief waar de patient bijna absoluut centraal staat. De arts belooft 'ik verbind mij plechtig mijn leven te wijden aan de dienst van de mens....'. De professionaliteit van de arts kwam nagenoeg uistluitend ter sprake voor zover deze betrekking had op het zieke individu. De eed heeft echter diverse veranderingen ondergaan, zich telkens aanpassend aan de inzichten en noden van de tijd. Zo blijft in de gewijzigde versie van 2003, de patient de centraal staan, maar wordt voor het eerst ook gewezen wordt op de verantwoordelijkheid van de arts naar de maatschappij. Nog steeds belooft de arts "ik zal de geneeskunst zo goed ik kan uitoefenen ten dienste van mijn medemens", maar ook 'ik zal daarbij mijn verantwoordelijkheid voor de samenleving kennen', hetgeen nog verder wordt bepaald als 'Ik zal de beschikbaarheid en toegankelijkheid van de gezondheidszorg bevorderen'.

Waar de laatste jaren er nog verdere discussie bestaat of een artseneed bij de start van de uitoefening van het beroep wel zinvol is, is ongeveer paralel hiermee aan een document gewerkt waarin competenties beschreven worden waar jonge artsen zich gedurende hun opleiding in dienen te bekwamen en waar toegang tot zorg opnieuw ter sprake komt maar nu ook organisatie van zorg en financiele aspecten.

Deze relatief nieuwe verantwoordelijkheid maakt de positie van de arts in de spreekkamer niet makkelijker, vooral als er een conflict kan bestaan tussen het belang de individuele patiënt en het belang van de (steeds meer interfererende) maatschappij. Rede temeer om een aantal maatschappelijk-economische aspecten van reumatologische aandoeningen toe te lichten en na te denken hoe verantwoordelijkheden voor het zieke individu en de maatschappij hand in hand kunnen gaan.

\section{Arbeidsparticipatie}

Deelname in het arbeidsproces. Dit eerste paneel van het drieluik belicht een gevolg van ziekte dat bij uitstek relevant is voor de patient, en tegelijk voor de maatschappij.

\section{Relevantie vanuit historisch perspectief}

Huizinga mag dan benadrukken dat de mens een Homo Ludens is, archeologen vinden evenveel argumenten dat de mens al vanaf het prille begin een Homo Faber is. Vele eeuwen werkte deze homo faber nagenoeg exclusief voor het levensonderhoud van zichzelf en zijn directe familie. Stilaan gaat de mens echter ook 'in dienst' van een ander werken en ontvangt hij een loon voor zijn levensonderhoud. Nog later werkt hij ook voor de maatschappij aan wie hij belasting betaalt in ruil voor publieke diensten zoals aanvankelijk vooral veiligheid, en later ook voor mobiliteit, onderwijs, cultuur. Zonder arbeid zou onze maatschappij niet bestaan. Arbeid, maar ook het geheel van sociale maatregelen waaronder inkomens-garantie bij ziekte, is uitgegegroeid tot een universeel recht van de mens 
ledereen (ook een zieke) heeft recht op werk

... en op correcte arbeidsvoorwaarden

Universal declaration of the Human rights 1948

In Nederland zijn aandoeningen van het bewegingsapparaat, samen met mentale aandoeningen, nog steeds verantwoordelijk voor $2 / 3^{\text {de }}$ van alle arbeidsongeschiktheid. Ons onderzoek naar arbeidsparticipatie bij reumatische aandoeningen concentreert zich hoofdzakelijk op ziekte van Bechterew of ankyloserende spondylitis (AS). Dit is een ziekte die zich kenmerkt door ontstekingen in de wervelzuil en vaak in andere gewrichten. De klachten van pijn, stijfheid en beperkingen beginnen vaak al in de $3^{\text {de }}$ levensdecade wanneer mensen belangrijke keuzes maken binnen hun sociale rollen en hun professionele carriere starten. Dat maakt deze ziekte toch wel sterk verschllende van reumatoide artritis, waar de ontstekingen vooral in de kleine hand en voetgewrichten aanwezig is. Reumatoide artritis treft bovendien vaker vrouwen en start in de 4 de levensdecade wanneer men volop druk is, om de in de diverse sociale rollen goed te kunnen presteren.

Het belang van werk voor de patienten blijkt uit diverse onderzoeken. Het hebben van betaald werk behoord samen met 'relatie met de partner' en 'relatie met kinderen' tot de drie belangrijkste sociale rollen, belangrijker dan vrije tijd, reizen, relaties met vrienden. Dat is voor patiënten met AS net zoals voor gezonden. Belamgrijk is echter te beseffen dat patienten het belang van elke sociale role voor hun leven, dus ook het werk, een hoger geven dan mensen zonder chronische aandoening. Alsof het besef van mogelijk verlies, al deze rollen waardevoller maakt.

\section{Onderzoek naar arbeidsparticipatie}

Het model van waaruit we de impact van AS (en andere reumatische aandoeningen) op werk in kaart brachten is vrij eenvoudig. Het maakt duidelijk dat arbeidsparticipatie een continuum is waarin we subdomeinen afgrenzen. lemand met een chronische aandoening kan gerust een normaal werkvermogen en productiviteit hebben. Wanneer de ziekte een bepaalde impact heeft kan het werkvermogen of de productiviteit terwijl men op het werk is verminderen (een fenomeen dat presenteeisme wordt genoemd. Wanneer beperkingen toenemen, kan het zijn dat aanwezigheid op het werk niet mogelijk is en is er sprake van ziekteverzuim of absenteïsme. Ultiem, vaak na meerdere en langdurige periodes van verzuim, kan een situatie onstaan dat duurzame terugkeer naar het werk niet meer mogelijk is en een procedure tot arbeidsongeschiktheid wordt gestart (waarbij de zieke zijn arbeidscontract zal verliezen).

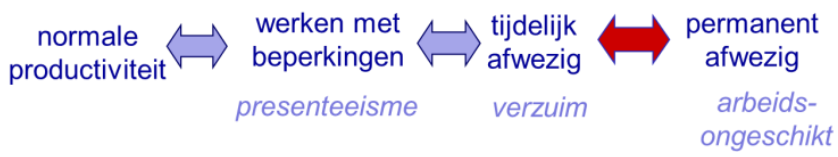

Onze afdeling doet veel onderzoek naar de manier waarop men uitkomsten van ziekte, hier dus arbeidsongeschiktheid, verzuim of presenteeisme, het best meet door middel van vragenlijsten. In onderzoek wordt immers vaak gebruik gemaakt van gegevens die door middel van vragenlijsten rechstreeks bij patienten verzameld worden. Het spreekt vanzelf dat de kwaliteit van de vragenlijsten daarbij essentieel is. Vragenlijsten moeten daarbij voldoen aan een aantal goed 
omschreven zo genoemde test-kenmerken. Om het wat concreter te maken ziet u op de dia inmiddels een voorbeeld van de een vragenlijst naar presenteeisme. Dit voorbeeld betreft de structureel meest eenvoudige vorm van een vragenlijst, namelijk één globale vraag naar productiviteit van de bevraagde persoon. Ik wil u uitnodigen deze vraag voor uzelf te beantwoorden. $U$ zal expleciet maar ook impleciet allerlei overwegingen maken terwijl u zichzelf een score probeert te geven.

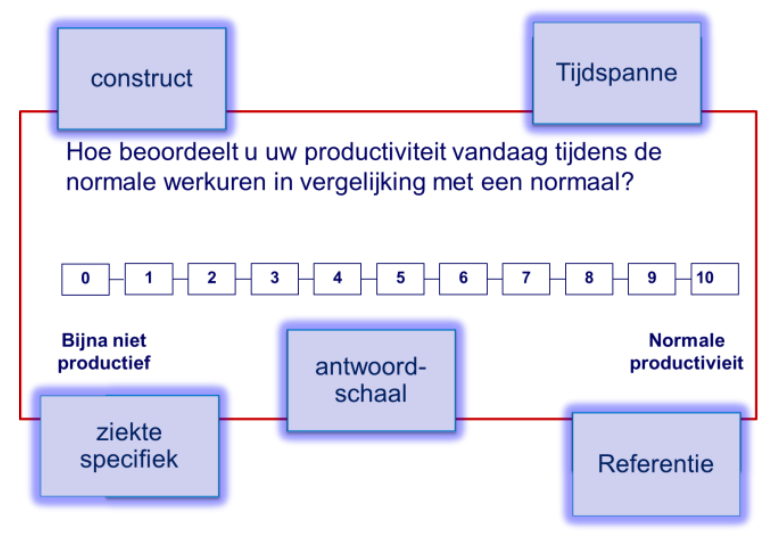

Samen met een groep internationale onderzoekers binnen OMERACT (Outcome Measurement in Rheumatology) die interesse delen in het meten van arbeidsparticipatie, vergelijken we de test-kenmerken van 24 al bestaande vragenlijsten over de impact van ziekte op arbeid. Dit gebeurt in een proces dat te vergelijken is met een soort afval-race waarbij de testkenmerken waaraan de vragenlijsten moeten voldoen steeds strikter worden. Het uiteindelijke doel is tweeledig. Vooreerst willen we een keurmerk geven aan de vragenlijsten die aan de vooropgestelde eisen voldoen, maar evenzeer willen we overeenkomst bereiken met alle onderzoekers, welke van deze beste overgebleven vragenlijsten we minstens zullen meten alle studie naar arbeidsparticipatie. Zo zal vergelijken en zelfs samenvoegen van resultaten van studies veel beter mogelijk worden.

Laten we de wereld van het 'meten' nu even achter ons liggen en liever naar resultaten kijken. Ons onderzoek vergeleek voor het eerst diverse aspecten van arbeid bij patienten met ankyloserende spondylitis met de arbeidsparticipatie in de algemene bevolking. Het bleek dat patienten in Nederland een bijna drie keer hogere kans hebben om arbeidsongeschikt te worden in hun werkzame leven en dat zij bijna helft meer verzuimdagen hebben. Patienten werken gemiddeld twee dagen per week terwijl ze klachten hebben en geven aan hun productiviteit tijdens het werken een score van zeven en een half $(7,5)$, waar 10 maximaal productief is. Daardoor hebben ze een klein uur per week extra tijd nodig te hebben om hun werk af te maken. Door de verhoogde kans op arbeidsongeschiktheid heeft een gemiddelde patiënt een inkomensverlies van 1400 Euro bruto per jaar. De maatschappelijke kosten voor verzuim en arbeidsongeschiktheid samen bedragen per patiënt 6300 euro per jaar wat voor de hele Nederlandse maatschappij een productieverlies van mogelijks 250 milj per jaar betekent (afhanelijk van welke prevalentie cijfers men hanteert voor ankyloserende spondylitis). Hoewel sommigen ook de kosten van presenteeisme berekenen, moeten we daar erg voorzichtig mee zijn, omdat het verband tussen de door de patiente gerapporteerde productiviteit en de objectief gemeten productivteit op de werkplek nog nauwelijks onderzocht is. In elk geval tonen deze resultaten dat de impact van AS (voor de patiënt en de maatschappij) wel minder groot is dan de impact van 
chonische rugklachten of rheumatoide arthritis, maar toch zeker nog substantieel, en ook groter dan reumatologen hadden verwacht.

Er is dus behoefte aan meer inzicht in factoren die arbeidsparticipatie beïnvloeden, om te kunnen voorspellen welke patienten problemen zullen hebben. Het is belangrijk ons te realiseren dat gelukkig de meerderheid van patienten met ankyloserende spondylitis geen extra verzuim hebben en niet arbeidsongeschikt worden. Integendeel, in een kleine additionele bevraging gaven we patiënten de mogelijkheid om de invloed van de ziekte op het werk een negatieve maar ook een positieve score te geven. Hoewel het gemiddelde voor de gehele groep negatief bleef (dus moeilikheden ervaart), gaf een kwart van de patiënten aan zich door hun ziekte juist zich extra in te zetten om productief te zijn. Het is tekenend dat we veelal onderzoeken wat de negatieve impact van ziekte is en minder stil staan bij mogelijke positive effecten. We moeten oppassen dat te veel nadruk op mogelijke problemen bij arbeidsparticipatie niet discriminerend werken tegen patiënten met chronische ziekten.

Om dan toch te weten welke patiënten risico hebben op uitval uit het werk, maakten we opnieuw gebruik van een eenvoudig model, het bio-psycho-sociaal model van de Wereld Gezondheids-Organisatie (WHO). Dit erkent dat de manier waarop mensen functioneren (en dus ook participeren in het arbeidsproces) niet alleen het resultaat is van de rechtstreekse gevolgen van de ziekte op het lichaam (biomedische factoren zoals pijn, veminderde beweeglijkheid en beperkingen bij actviteiten), maar ook in belangrijk mate beïnvloed wordt door factoren in de omgeving of in de persoonlijkheid van de patiënt. Dit soort factoren noemt men contextuele factoren. Uit een aantal onderzoeken konden we concluderen dat biomedische of rechtstreeks ziekte gerelateerde factoren, vooral fysieke beperkingen en pijn, ongeveer $2 / 3^{\text {de }}$ verklaren van alles wat we kunnen verklaren in de relatie ziekte $\leftrightarrow$ arbeid. De andere facoren die bijdragen liggen dus in de context van de patient met volgens diverse onderzoeken vooral een negatieve invloed op arbeid van zwaar belastende beroepen, van (vooral in recentere studies) de negatieve houding van collega's en leidinggevenden en van de manier waarop de patiënt zelf omgaat met zijn pijn en beperkingen. Als eenvoudig maar typisch voorbeeld van het belang van de interactie tussen de ziekte, de contextuele factoren en werkvermogen verwijs ik naar een patiente die antwoordde op de vraag of op het werk alles wel goed ging ondanks haar reumatische ziekte. 'Zoals mijn pijn en beperkingen nu zijn kan ik mijn werk wel aan, maar als ik de job van mijn man zou hebben, dan zou dat onmogelijk zijn". Contextuele factoren verdienen dus net als het behandelen van de ziekte zelf, aandacht wanneer we de arbeidsperspectieven van onze patienten willen verbeteren

Ook het onderzoek naar contextuele factoren in relatie tot arbeid, doen we nu samen met de eerder genoemde internationale werkgroep binnen OMERACT. Van een classificatie die we maakten van 11 mogelijke soorten contextuele factoren, gaan we nu na voor welke factoren de bewijskracht voor hun invloed op de relatie ziekte $\leftrightarrow$ werk zo hoog is, dat we deze contextuele factoren zouden moeten meenemen in alle studies waar arbeid een uitkomst is. Gegevens over de contextuele factoren zullen helpen om de resultaten van studies en verschillen in resulaten tussen studies correcter te interpreteren. Ook hier willen we vervolgens een keurmerk toekennen aan de specifieke vraag/methode die de geselecteerde contextuele factor (internationaal) het meest accuraat en betrouwbare meet. Hoe eenvoudig het ook mag lijken om bijvoorbeeld ' zwaar belastend werk' te meten, er is hierover allerminst consensus. Er bestaan talloze classificaties, van zeer eenvoudig tot zeer ingewikkeld, en we weten nog steeds onvoldoende welke hiervan arbeidsproblemen het best voorspelt en tegelijk makkelijk bruikbaar is in klinische studies of de praktijk. 
Bij het voorspelen van verzuim en arbeidsongeschiktheid is er echter nog een andere voor de hand liggende kandidaat-voorspeller het betreft de vraag naar presenteeeisme. Dat is niet zo verassend. We weten in de geneeskunde zeer goed dat binnen eenzelfde spectrum van uitkomsten de ene uitkomst de andere kan voorspellen. Zo hebben patienten druk of de borst of angina pectoris een grote kans op een hartinfarct. Recent hebben we dan ook aangetoond dat de score voor presenteeisme een sterke voorspeller is voor verzuim de komende zes maanden en zelfs een veel betere voorspeller dan de ziekte-activiteit of het fysiek functioneren.

\section{Bespiegeling voor de arts in de spreekkamer}

Een aantal van de genoemde bevindingen stimuleerden ons om met enkele ander Nederlandse reumatologen en reumaverpleegkundigen een initiatief te starten om in reumatologische praktijk actief een arbeids-anamnese in te voeren, dit wil zeggen te vragen aan de patient naar zijn arbeidsvermogen tijdens het artsbezoek. Op zich is een dergelijk arbeidsanamnese al deel van de behandelrichtlijn (altans voor reumatoide arthritis), maar ze is onvoldoende geïmplementeerd.

Waar het lovenswaardig is dat in Nederland de eigen arts niet betrokken is bij de formele rechtvaardiging van verzuim of arbeidsongeschiktheid, heeft de splitsing in bevoegdheden tussen eigen arts en bedrijfsarts geleid tot het idee, dat de behandelende arts geen aandacht mag hebben voor arbeid. Dit is kunstmatig is nu we beseffen dat arbeid een belangrijk aspect is voor het leven van de patient en dat we in de kliniek vroege tekens kunnen opsporen die kunnen leiden tot arbeidsproblemen.

Binnen Target@Work willen we aan artsen een handreiking bieden hoe zij op een positieve en eenvoudige manier in de spreekkamer kunnen vragen naar de relatie tussen ziekte en werk. Maar ook willen we inzicht geven in de mogelijkheden om hulp te bieden aan patienten in periodes dat werken met ziekte moeilijk blijkt. Zo kan de arts bijdragen aan een rol die voor patienten belangrijk is, maar ook bijdragen aan de een samenleving waarin mensen beter en langer kunnen participeren in het arbeidsproces.

\section{Economische evaluaties van medische technologieen}

Het middenpaneel van mijn drieluik betreft de betaalbaarheid van de zorg. Het is duidelijk dat de uitgaven aan gezondheid voortdurend en om heel verscheiden redenen stijgen en zullen blijven stijgen. De kosten voor zorg groeien sneller dan de economie. Waar in 'arme' landen die weinig uitgeven aan gezondheidszorg, ook kleine investeringen kunnen resulteren in grote gezondheidswinst, is dat niet meer noodzakelijk zo in rijkere landen. Het is dus begrijpelijk dat beleidsmakers vooraleer ze nieuwe technologieen of therapieen terugbetalen eerst willen geinformeerd zijn in welke mate extra investeringen (want nieuw is meestal ook duurder) resulteren in betere gezondheid. In dit luik krijgt woord 'waarde' zijn meest gebruikte betekenis; dat wat men bereid is te betalen. Gelukkig is de Nederlandse maatschappij bereid heel wat te betalen voor gezondheid. Gezondheid heeft immers voor onze samenleving ook een hoge intrinsiek of ideele waarde, de eerste betekenis van het woord. Toch zijn er grenzen aan de betaalbaarheid.

De methode om in de gezondheidszorg na te gaan wat de extra financiele middelen zijn die men nodig heeft om een bepaalde gezondheidswinst te bereiken heet een 'economische evaluatie' en meer specifiek een 'kosteneffectiviteit analyse'. 


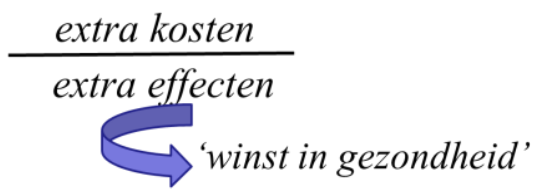

Relevantie vanuit historisch perspectief

Laten we ook hier beginnen, een beetje dichter bij het begin. Het systematische bijhouden van een boekhouding van de zieken- en armenhuizen werd in Nederland verplicht in 1851 . Een vergelijking tussen de kosten van een verpleegdag in 1897 en 1997 leerde dat de kostprijs steeg van 1 gulden 13 naar 973 gulden per dag. In termen van koopkracht, uitgedrukt in relatie tot de broodprijs, een maat om historische prijzen te vergelijken, betekent dit dat in 1897 een verpleegdag 3 broden kostte en 100 jaar later 325 broden. Waar in 1897 de kosten van voeding de grootste uitgavenpost was (38\% van de verpleegdag) betrof dat 100 jaar later salarissen (50\%) en gebouwkosten (30\% van de verpleegdag). Opgemerkt moet worden dat in deze verpleegdagprijs nog niet eens de uitgaven aan technische onderzoeken meegenomen zijn. Om deze toename in kosten enigszins af te zetten tegen gezondheidswinst: in 1897 bedroeg de levensverwachting van een man 47 jaar en 100 jaar later was dat 75 jaar.

Het moment dat men in de gezondheidszorg bewust kosten ging afwegen tegen effecten is niet heel duidelijk. In de reumatologie werd exact 25 jaar geleden de eerste kosten-effectiviteits analyses gepubliceerd en het betrof de behandeling van reumatoide artritis met goud tabletten tov geen behandeling. Het was een zeer kosten-effectieve therapie.

\section{Onderzoek rondom economische evaluaties}

Zelf deden we diverse kosten-effectiviteitsanalyses bij reumatoide artritis en ankyloserende spondylitis en meest recent hebben we vooral gewerkt aan computersimulatie modellen om de kosten-effectiviteit van de biologische geneesmiddelen bij dezen twee ziekten beter te begrijpen. Immers, een van de grote veranderingen in de reumatologie de laatste 15 jaar is immers de beschikbaarheid van 'biologisch' ontwikkelde geneesmiddelen. Dit betreft eiwitten die in laboratoria gemaakt worden en die een heel precieze invloed kunnen uitoefenen op het ziektproces door rechstreekts het verstoorde biologische process te herstellen. Waar deze medicijnen medische belangsteling kregen omwille van hun grote werkzaamheid, kregen ze vooral publieke belangstelling door hun prijs! Deze middelen zijn duur, extreem duur. Waar de medicatiekosten van een behandeling van ernstige reumatoide arthritis zonder biologische middelen maximaal 800 euro per jaar is, stijgt dit naar 15,000 tot 20,000 euro per jaar als we biologische middelen inzetten.

De resultaten van onze kost-effectiviteit analyses toonden dat de behandeling van ankyloserende spondylitis met biologische geneesmiddelen gezondheids-economisch gunstiger was dan voor rheumatoide arthritis, waar de kosteneffectiviteit aan de hoge kant is van wat de Nederlandse maatschappij een acceptabele investering in gezondheid vindt. Daar zijn diverse redenen voor. De voornaamste is dat voor de behandeling van AS geen alternatieve behandelingen zijn om de ziekteactiviteit te onderdrukken, terwijl er voor reumatoide arthritis vaak wel 
alternatieven behandelingen beschikbaar zijn zijn die ook gezondheidswinst kunnen geven, maar aan een veel lagere pijs.

Het boeiende van economische modellen is nu dat zij niet alleen een getal (of liever ratio) geven aan kosten-effectiviteit, maar vooral dat ze ook erg behulpzaam kunnen zij om factoren te identificeren die belangrijk bijdragen aan de kosten-effectiviteit en daardoor richting kunnen geven aan onderzoek om kosten-effectief gebruik te verbeteren. Modellen kunnen immers berekenen in welke mate de betaalbaarheid gunstiger wordt als we, bijvoorbeeld, accurater de patiënten kunnen identificeren die geen biologische middelen nodig hebben. Vervolgens kan het model dan weer berekenen hoeveel financiele ruimte er dan vrijkomt om zo'n voorspel- of selectie test (een biomarker of genetisch profiel bijvoorbeeld) te kunnen ontwikkelen en in de praktijk in te zetten. Van deze zeer boeiende mogelijkheden wordt veelte weinig genrui gemaakt bij het plannen van onderzoek of bedenken van behandlstrategieen.

Maar toch, hoe zeer we ook kunnen en zullen proberen om dure geneesmiddelen en technieken zo optimaal mogelijk in te zetten, toch begrijpt $u$, dat we toenemend in het gebied komen waar dilemma's ontstaan in de spreekkamer omdat een de arts voor de patient die voor hem zit, toch liever kiest voor het medicijn (of techniek) met een zekerder en een sneller effect, al is dat duurder. Zulke 'belangenconflicten' doen zich toenemend voor bij nagenoeg alle specialismen. Diverse oplossingen worden aangedragen; persoonlijke bijdrage door de patienten, terugbetaling door de ontwikkelaar (industriele partner) bij onvoldoende effect, maar allen hebben een keerzijde.

Een belangrijk punt bij deze discussie over kost-effectiviteit en dat ik als arts graag wil toelichten, is hoe we gezondheid meten en hoe we nagaan welke gezondheidswinst relevant is. Traditioneel worden de effecten van nieuwe medicaties of technologieën immers gemeten op basis van uitkomsten waarop het grootste effect te verwachten is en die toch relevant zijn. Zo worden bijvoorbeeld de effecten van medicijnen voor osteoporose traditioneel gemeten aan het verminderen van het aantal fracturen, en van effecten medicijnen voor ontstekingsreuma aan de daling in ziekteactiviteit. In een economische evaluatie wil men echter weten wat het effect is op de algehele gezondheid. Niet zo gek natuurlijk en bovendien de enige manier om het effect van verschillende interventies bij verschillende ziekten te vergelijken. Over het meten van gezondheid ten behoeve van economische evaluaties is in de 70 jaren van de $20^{\text {ste }}$ eeuw hard nagedacht. Een fundamenteel uitgangspunt daarbij, is dat de echte waarde voor gezondheid veel beter kan bepaald worden aan de hand van keuze-experimenten (u ziet een voorbeeld op de dia) waarbij de deelnemer diverse keren moeten kiezen tussen specifieke gezondheidstoestanden of -profielen. $U$ wordt nu gedwongen te kiezen welke aspecten van gezondheid voor u echt belangrijker zijn dan andere aspecten. Dit soort informatie (een relatieve waardering) mist men als men gebruik maakt van klassieke vragenlijsten waarin patienten aankruisen in welke aspecten van gezondheid zij problemen ervaren. Een verdere vereistte is dat de uiteindelijke waarde voor gezondheid moet uitgedrukt worden op een schaal van 0 tot 1, waarbij 'nul' staat voor een gezondheid even slecht als 'dood' en ' 1 ' voor een 'perfecte gezondheid'.

Onderzoek dat we deden naar test-kenmerken van bestaande methoden om gezondheid te waarderen toonde dat verschillende methoden, zeer uiteenlopende resultaten gaven over de gezondheidswinst. Zo verschillend zelfs dat met de ene methode een behandeling kost-effectief zou zijn maar niet met de andere methode. Daarom startten we een initiatief om een nieuwe vragenlijst te ontwikkelen om gezondheid te meten en gezondheidstoestanden te waarderen. We gingen er daarbij van uit dat een van de belangrijke redenen van de onvergelijkbaarheid van 
bestaande methoden toegeschreven kon worden aan de inhoud van de bestaande vragenlijsten/gezondheidstoestanden die onvoldoende rekening houden met de specifieke problemen die de patienten met verschilende aandoeningen kunnen hebben.

We wilden daarom de inhoud van onze vragenlijst wel specifiek maken voor de gezondheidsproblemen passend bij de ziekte. Om vergelijkbaarheid tussen ziekten te behouden vonden we het wel belangrijk uit te gaan van een universeel model van gezondheid. Daartoe gebruikten we opnieuw het model van de Wereld Gezondheids-Organisatie. Gekoppeld aan dit model is er ook een classificatie van alle bouwstenen die nodig zijn om gezondheid te defineren. De aanname is dat al die bouwstenen op een verschillende plaats in het unidimensionele construct gezondheid liggen. Patienten met verschillende aandoeningen kunnen dus moeilijkheden ervaren in andere specifieke bouwstenen. Voor de waardering van gezondheid mag dat in principe geen verschil maken, zolang we de gezondheidstoestanden die resulteren uit deze specifiek problemen maar blijven verankeren (op een technisch correcte manier) op een schaal van nul (even erg als dood) tot 1 (perfect gezond).

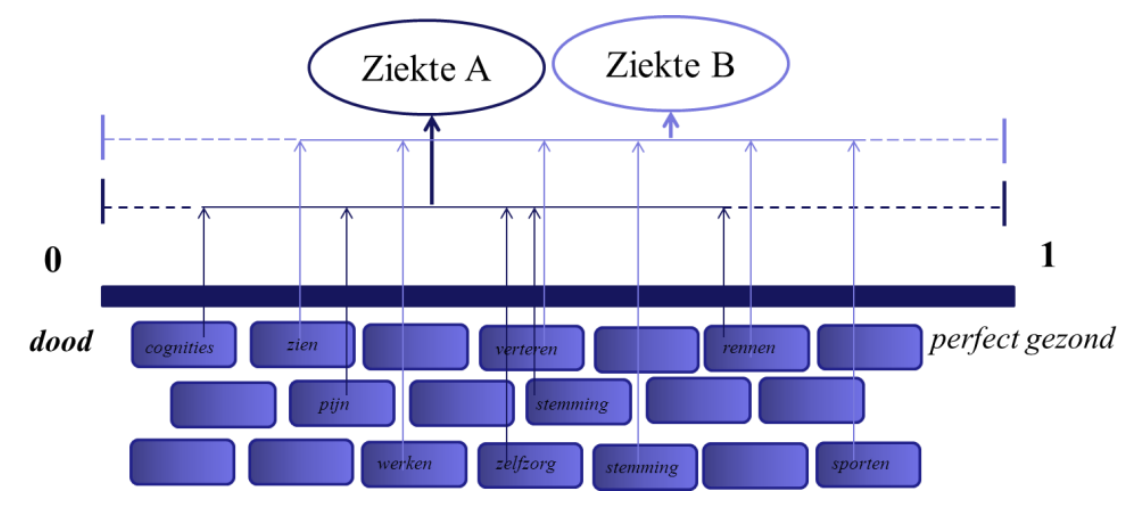

In ons onderzoek bij patiënten met ankyloserende spondylitis hebben we op basis van deze genoemde uitgangspunten inmiddels en vragenlijst ontwikkeld die de specifieke problemen weerspiegelt van patiënten met deze ziekte. Inmiddels zijn we bijna klaar om het experiment uit te voeren waarbij de gezondheidstoestanden die we kunnen onderscheiden op basis van deze vragenlijst, kunnen laten waarderen door patiënten maar ook gezonde mensen, ok de waardering van gezondheid voor patiënten met deze ziekte zetten we inmiddels laatste stap te zetten in de waardering van gezondheid (door patiënten en gezonde mensen) van gezondheidstoestanden die volgens de beschreven methode ontwikeld is. We menen dat deze methode een betere benadering is om ook in economische evaluaties de waarde voor gezondheidswinst te meten en en te dienen als uitgangspunt om verder te begrijpen welke veranderingen in gezondheid over de tijd relevant zijn.

\section{Bespiegeling voor de arts in de spreekkamer}

Zijn economische evaluaties ook nuttig voor artsen in de praktijk, of dienen ze alleen om beleidsmakers te helpen bij de beslissingen omtrent de terugbetaling van nieuwe technologieën of behandelingen? Ik moet toegeven dat artsen vaak weifelachtig staan tegenover kosteneffectiviteits modellen, vooral omdat ze vinden dat bij het operationeel maken van zulke computermodellen te veel onzekerheden zijn. Op zich klopt dat ook, maar het is precies uit de onzekerheid dat we leren (geen zwarte doos, maar een doos van Pandora). Bovendien dienen we 
ons te realiseren dat budget beperkingen meer en meer aanwezig zijn in de spreekkamer, en dat de arts toch belangrijke speler is in het budget beheersing want hij is het die voorschrijft.

- Naast aandacht voor effectiviteit en veiligheid als voornaamste criterium voor medische beslissingen, kan inzicht in de elementen van de kosteneffectiviteit, en vooral reflectie over de echte gezondheidswinst die we zullen bereiken, helpen doelmatigere keuzes te maken (choose wisely):

- Waar we op die manier geld sparen, kunnen we het immers investeren in gezondheid van patiënten waarvoor geen goedkopere alternatieven beschikbaar zijn

- Uitdrukkelijk hoop ik dat de arts de afwegingen over kosteneffectiviteit maakt vanuit een maatschappelijk perspectief, het perspectief dat boven de kosten van de eigen praktijk, verzekeraar of ziekhuis staat en de gehele samenleving ten goede komt

\section{Socio-economische factoren en hun invloed op gezondheid}

In het derde en laatste paneel van het drieluik keren we de richting waarin we kijken om, en vragen we ons niet af wat de impact is van ziekte op socio-economische uitkomsten maar in welke mate socio-economische kenmerken van het individu of zijn omgeving invloed hebben op gezondheid

Belang van socioeconomische determinanten van gezondheid vanuit historisch perspectief Laten we weer even beginnen bij het begin. De kloof in toegang tot gezondheid tussen sociale standen was eeuwenlang schrijnend. De arts is historisch een vrijgevestigd beroepsbeoefenaar en nagenoeg alleen mensen uit de sociaal betere klassen konden zich een artsbezoek veroorloven. Arme zieken konden in de liefdadigheid terecht, in armenhuizen en gasthuizen, waar alleen in uitzonderlijke gevallen een stadsarts om hulp geroepen werd. Gelukkig hebben de meeste WestEuropse landen gekozen in de $19^{\text {de }}$ eeuw voor een systeem waarin gezondheid een (minstens gedeeltelijke) publieke aangelegenheid werd, met een wisselende mate van solidariteit met zieken en vooral arme zieken. Toch blijft sociale ongelijkheid in gezondheid bestaan en vraagt aandacht, zeker nu ook in ontwikkelde landen de kloof tussen arm en rijk weer toeneemt.

\section{Onderzoek naar scio-economische determinanten van gezondheid}

Ten behoeve van ons onderzoek gebruiken we twee eenvoudige werkkaders. Het eerste betreft een acroniem, PROGRESS, een Engels letterwoord dat samenvat rondom welke SE factoren er ongelijkheden in gezondheid kunnen bestaan. De meest bestudeerden factoren in de reumatologie zijn opleiding (Education) en inkomen (Social Capital), maar ook op basis van beroep (Occupation), woonplaats (Place of residence), afkomst (Race), religie (religion), sociale status (Social capital) en natuurlijk geslacht (gender) kunnen ongelijkheden in gezondheid bestaan. Het tweede werkkader betreft het model voor ' toegang tot zorg' van de Wereld Gezondheids Organisatie. Toegang tot zorg wordt hierin bepaald door drie aspecten, ten eerste de beschikbaarheid van een medicijn, test of gezondheids-dienst, ten tweede de betaalbaarheid en ten derde aanvaardbaarheid. De eerste twee begrippen spreken voor zichzelf. Als voorbeelden waar aanvaardbaarheid van zorg een discussie kan zijn, kan men denken aan esthetische ingrepen of wilsbeschikking met betrekking tot levensbeëindiging bij minderjarigen. 


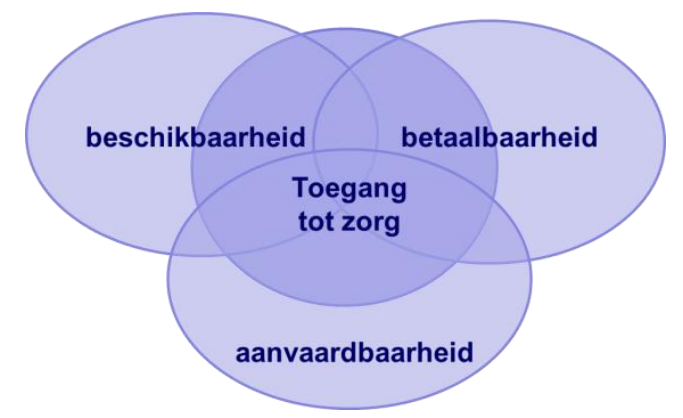

Een belangrijk concept in onderzoek naar SE-factoren en gezondheid betreft de overweging of verschillen in gezondheid door zulke factoren louter ongelijkheden betreffen dan wel ook onrechtvaardig en/of vermijdbaar zijn. Dit belangrijke onderscheid is vervat in de woorden ongelijkheid en ongelijkwaardigheid (of mooier in het Engels inequality en inequity). Het zijn natuurlijk de ongelijkwaardigheden in gezondheid die we in onze maatschappij willen mimimaliseren.

Het meest treffende onderzoek dat we hieromtrent deden sloot aan bij de economische aspecten van dure biologische geneesmiddelen. We realiseerden ons dat met huidige prijsregeling van geneesmiddelen in Europa, de marktprijs van biologische middelen niet heel sterk zouden verschillen tussen hoge en lage inkomlanden. We vroegen ons af, wat dat voor patiënten met reumatoide artritis zou betekenen met betrekking tot toegang tot deze geneesmiddelen en welk effect dit zou hebben op gezondheid? We verzamelden feiten over toegang tot biologische geneesmiddelen in 46 landen die tot geografische Europa behoren. Wat betreft beschikbaarheid blijkt er in 10 van de 46 Europese landen geen enkel biologisch geneesmiddel terugbetaald. Dit treft allemaal lage inkomlanden. Hoe rijker een land is, hoe meer soorten biologische middelen beschikbaar zijn. Op het gebied van betaalbaarheid, kunnen de kosten van een jaar behandeling met een biologisch middel in lage inkomlanden oplopen tot 11 keer het jaarlijks bruit nationaal product (BNP) per hoofd van de bevolking. Waar de mate van toegang (gemeten met een index die we zelf op basis van diverse factoren samenstelden) sterk bepaald wordt door de welvaart gemeten aan BNP van het land (donkerder grijs op de kaart van Europa betekent minder toegang) was de allerbelangrijkste bevinding toch dat een beperkte toegang tot biologische middelen ook gepaard gaat met slechtere controle van de ziekte. Het hoeft geen discussie dat deze ongelijkheid in toegang louter op basis van het land waar je woont als reumapatient extreem onrechtvaardig is.

Ook in eigen land echter, toonden we ongelijkheden in gezondheid aan op basis van SE factoren. We onderzochten de invloed van diverse PROGRESS factoren op gezondheid in een bestand van het Reumafonds met gegevens over bijna 9000 volwassen Nederlanders. De conclusies van het onderzoek zijn indrukwekkend. In Nederland hebben mensen met een lagere beroepsopleiding 70\% meer kans op een aandoening van het bewegingsapparaat en mensen met een middelbare beroepsopleiding $30 \%$. Een sterker risico op ziekte zagen we bij mensen die leven van een bijstandsuitkering, die 3 keer (300\%) vaker een aandoening hebben van het bewegingsapparaat. Afkomst (eerste of tweede generatie niet Westerse geboorteland) of woonplaats (gebaseerd op postcode) hield in ons onderzoek (gelukkig) geen verband met het hebben van ziekte. Het boeiende van onze studie was dat het we het verband tussen socio-economsiche factoren en ziekte bij de 5 belangrijkste chronische aandoeningen konden nagaan. De effecten die we zagen voor aandoeningen van het bewegingsapparaat, zagen we in grote lijnen ook we ook voor hart en vaatziekten, diabetes, mentale aandoeningen en longziekten, ook wanneer we rekening hielden met verschillen in leeftijd, geslacht, rookgewoonte en gewicht. 
Wannneer we vervolgens bestudeerden of socio-economische facoren bij mensen die één van deze ziekte hebben ook resulteerde in slechtere gezondheid zagen we opnieuw dezelfde effecten. Patienten die lager opgeleid zijn of leven van een bijstandsuitkering hebben een fors slechtere gezondheid en opnieuw was de grootte van dit effect redelijk vergelijkbaar voor alle chronische ziekten die we bestudeerden.

Verklaringen voor deze effecten zijn complex. In ons onderzoek hadden leefstijl, vooral roken en gewicht zeker duidelijke relatie met het hebben van ziekte en met de mate van ongezondheid, maar zij konden het effect van de SE factoren hierop niet te verklaren. Omdat we vergelijkbare invloed zien bij nagenoeg alle ziekten, moet er, tenminste gedeeltelijk, een gezamenlijke onderliggende rede zijn. Gezondheidsgeletterdheid is een kandidaat om een deel van dit gezamelijk effect te verklaren.

Bespiegeling voor de arts in de spreekkamer

Ook hier is er de vraag of de arts in de praktijk een rol kan spelen bij het verminderen van sociale ongelijkheid in gezondheid. Die rol is natuurlijk zeer beperkt als het de prijsstelling van medicatie tussen landen betreft. In ons eigen land moeten we ons wel realiseren dat we leven in een tijd waar gezondheidszorg beetje bij beetje gecommercialiseerd wordt en riskeert minder universeel toegankelijk te worden, maar vooral dat gezondheidszorg complexer wordt en dus zeker ook voor patienten moeilijk te begrijpen, terwijl wij verwachten dat ze meer en meer verantwoordelijkheid nemen over hun ziekte en behandeling. Aandacht voor patienten met minder socioeconomische draagkracht lijkt belangrijk als we willlen voorkomen dat de gezondheidskloof groter wordt. Net zoals 'ouderen-vriendelijke ziekenhuizen' zouden we ook extra aandacht kunnen hebben voor mensen die minder weerbaar in onze gezondheidszorg om andere redenen dan ouderdom.

\section{Samenvatting}

Wanneer we terugkijken naar het drieluik van maatschappelijke aspecten van reumatologische aandoeningen, is het middenpaneel wel het allerbelangrijkst. Centraal staat immers de opdracht om af te wegen of ons handelen resulteert in gezondheidswinst die relevant is, die niet bereikt kan worden met bestaande alternatieven en die redelijkerwijs betaalbaar is. Daarnaast staan aan de ene kant aandacht voor 'arbeid', een waarde die aanvullend is aan gezondheid en aan de andere kant aandacht voor 'gelijkwaardigheid in toegang tot zorg' een de waarde die voor zichzelf spreekt.

Meen in nu echt dat deze waarden (en nog vele nadere 'echte' waarden in onze gezondheidszorg!) weerloos zijn? Gelukkig niet, echte waarden overleven en krijgen vanzelf onze aandacht. Wel ben ik soms bezorgd dat wij in ons enthousiasme over nieuwe uitkomstmaten, behandeltargets, ziektecriteria, zorgvernieuwingsprojecten, financieringsstructuren, we aan deze belovende nieuwkomers te snel echte waarde toekennen, zonder zeker te zijn van de gezondheidswinst die we bereiken en de kosten die daar vaak (zoniet altijd) tegenover staan. Veel mooier dan ik het ooit kan zeggen, reflecteert Lucebert voor ons 'wat wordt wordt willoos, ...., en wordt van aanraakbaarheid rijk, als het hart van de tijd'.

\section{Dankwoord}

Nu ik heb mogen vertellen wat me boeit en wat de inhoud van mijn leeerstoel is, kom ik bij de traditionele afsluiting, waarbij ik de gelegenheid krijg een dankwoord uit te spreken. Bij een dankwoord horen bloemen. Door u deze symbolische bloemen te schenken, maak ik een belofte waar aan mijn collega's reumatologie die gevraagd hebben om 'ook iets te vertellen over Renoir'. 
Als jonge reumatoloog ontmoette ik immers bij toeval de kleinzoon van deze Franse impressionistische schilder. Pierre August Renoir leed aan een ernstige reumatoide arthritis. Zijn kleinzoon vertelde hoe zijn grootvader in een tijd dat men nog maar net de diagnose kon stellen en er eigenlijk geen behandeling beschikbaar was, op een onwaarschijnlijk moedige manier kon omgaan met de ziekte dankzij zijn persoonlijke creativiteit en vooral de ongelooflijke steun van zijn omgevig. Als hij bijvoorbeeld s'nachts wakker werd en niet meer kon slapen door de pijn en stijfheid in zijn handen, vroeg hij zijn vrouw hem een klein paneeltje te brengen, waarop hij dan bloemen schilderde. Deze bloemen bied ik aan iedereen die ik iedereen die ik dank verschuldigd ben.

Dank ben ik eerst verschuldigd aan het college van bestuur van de Universiteit Maastricht, de decaan van faculteit HMLS, raad van bestuur van het MUMC en mijn commissie van toezicht omdat zij het belangrijk vinden een leerstoel Maatschappelijke Aspecten van Reumatologische Aandoenigen te steunen. Enkele mensen wil ik bijzonder bedanken. Professor Vantrappen, mijn opleider inwendige geneeskunde en Professor Dequeker, mijn opleider reumatologie in Leuven. Professor van der Linden, beste Sjef $u$ begrijpt de kunst om de krijtlijnen van een afdeling duidelijk te trekken maar daarbinnen mensen ongelooflijke vrijheid te geven: ik heb de mogelijkheden die zich op onze onze boeiende afdeling voordeden dankzij mensen zoals professor Maarten Boers, professor Désiree van der Heijde en professor Robert Landewé slechts hoeven te grijpen en daarvoor steeds uw steun gekregen. Dank daarvoor. Professor Stehouwer, beste Coen, ook u biedt de reumatologie vrijheden en mogelijkheden. Dankzij De Maastricht Studie hebben we het onderzoek van onze afdeling kunnen verbreden en ons netwerk van contacten kunnen uitbreiden. Persoonlijk ben ik u dankbaar voor de steun en waardevolle adviezen rondom en na het emeritaat van prof van der Linden. Dr Vosse, beste Debby, mijn maatje op de afdeling. Met jouw engagement en inzet is de patientenzorg en de opleiding reumatologie in Maastricht in excellente handen. Grenzeloze dank.

ledereen werkzaam op en voor de afdeling reumatologie jullie bevestigen voor mij dat een mens beter wordt door omringd te zijn door goede mensen. Secretariaat, gespecialiseerde reumaverpleekundigen, studie verpleegkundige, poli assistenten, zonder jullie logistiek steun is zorg of onderzoek niet mogelijk! Arts-assistenten in opleiding tot reumatoloog. Jullie toewijding aan de patienten, enthousiasme, nieuwsgierigheid, en jullie loyaliteit naar elkaar zijn ongekend! De toekomst van jullie en de reumatologie ziet er goed uit! Promovendi en andere onderzoekers, jullie zijn de motor van ons onderzoek en eerlijk gezegd ook van mij. Op elk van jullie zal ik trots zijn als jullie straks jullie proefschrift zullen verdedigen. Collega's op afdeling, onze sterkte is dat we mekaar aanvullen en respecteren. Laten we dat vooral zo houden.

Hechte familie, trouwe vriendinnen, geduldige muziekleraren, onmisbare broers dank-julliewel om de zo noodzakelijke evenwichten des levens voor mij te bewaken. Papa en mama, wat zijn wij bevoorrecht met ouders als jullie. Jullie leerden ons dat echte verdiensten in het leven geen titel behoeft.

Mama, tot een jaartje geleden was jij er, altijd wel ergens, voor ons. Jou draag ik deze titel op. Jou beloof ik, dat ik hard zal werken om het ambt dat ik vandaag in het openbaar aanvaard verder waar te maken. Ik zal dat trachten te doen met waarden die jij soms benoemd, maar meestal gewoon voorgedaan hebt; verantwoordelijkheid met als kernen eerlijkheid en rechtvaardigheid, en zo vanzelfpsrekend voor jou, met toewijding en zorgzaamheid.

Evenzeer hoop ik, dat ik bij het uitoefenen van de taken die op mij wachten en die zonder twijfel boeiend zijn, maar ook complex, wanneer de belangen van individuen strijdig zijn met de 
belangen van systemen, of wanneer academische waarden weerloos worden door financiële overwegingen en structuren, ik het waard zal zijn gewoon een plek te mogen hebben als mens, tussen jullie, tussen allen.

Ik heb gezegd 